\title{
The Effect Instructional Approach and Authentic Assessment Toward an Achievement in Mathematics
}

\author{
Agnes M. Goni \\ Department of Primary School Teacher Education \\ Universitas Negeri Manado, Indonesia \\ agnesmaria0559@gmail.com
}

\begin{abstract}
The objective of the research is to figure out the effect of instructional approach, and assessment authentic toward students' achievement in mathematics after controlling students' previous ability. The method used in this research is experimental method with $2 \times 2$ factorial design. The samples of this research are the students of class $\mathrm{V}$ in SD at Tomohon which define by random sampling 80 students are to be chosen the samples. The results of the research after controlling the students' previous ability indicate that: (1) the achievement of mathematics students who used the realistic mathematics education approach is higher than the instructional by conventional approach, (2) the achievement of mathematics who students' used assessment authentic of portfolio is higher than the result of the achievement mathematics learning by paper and pencil, (3) there is an interaction effect between instructional approach and assessment authentic toward the achievement of mathematics, (4) for groups students who used realistic mathematics education, the achievement of mathematics assessment portfolio is higher than the by paper and pencil, (5) for groups students' by paper and pencil, the achievement of mathematics used approach realistic mathematics education is lower than the approach conventional, (6) for groups students' by portfolio assessment, the achievement of mathematics using approach realistic mathematics education is higher than the approach conventional, and (7) for groups students who used conventional, the achievement of mathematics assessment portfolio is lower than the by paper and pencil, conventional.
\end{abstract}

Keywords: instructional approach, assessment authentic, students' achievement in mathematics

\section{INTRODUCTION}

Mathematics learning in elementary school aims to: (1) train ways of thinking and reasoning in drawing conclusions, (2) developing creative activities involving imagination, intuition, and discovery by developing divergent thinking, originality, curiosity, making predictions and predictions and trying-try, (3) develop problem solving skills, and (4) develop the ability to convey information or communicate ideas, among others, through verbal talks, notes, graphs and maps [9].

Furthermore, the results of the analysis of the implementation of the Trends in International Mathematics and Science study conducted by Leung from The University of Hong Kong showed that there was more time spent in school in Indonesia, but the level of student achievement was low because most mathematical questions worked in classrooms were expressed in mathematical languages and symbols whose teaching is not related to daily life, as a result students feel afraid and lazy to learn mathematics [14]. It is also argued by [1] that the various subjects taught in school, math field of study that is considered the most difficult by the students, both of which are not learning disabilities and more so that learning disabilities.

Conventional mathematics learning results in students working procedurally and understanding mathematics without reasoning, besides the interaction between students and teachers during the teaching and learning process is very lacking, which results in students having difficulty in applying mathematics to real life situations. Whereas in mathematics learning at elementary school emphasizes the interrelationship between mathematical concepts and children's daily experiences. In addition, it is necessary to re-apply the mathematical concepts that children have in their daily lives or in other fields.

Approach Realistic Mathematics Education (RME) if in Indonesia known as the Mathematics Education realistic Indonesia (PMR) I was learning mathematics by using contextual issues that used to be realistic for the students, which is based on the experience they have. Mathematics as a human activity means that students must be given the opportunity to rediscover mathematical ideas and concepts with adult guidance.

The aforementioned efforts are carried out through exploring various realistic situations and problems but also in something that students can imagine [13]. This is the principle of rediscovery that can be inspired by various informal solving procedures in mathematical concepts. Realistic Mathematics Education is basically the use of reality and environment that is understood by students to facilitate the learning process of mathematics so that they can achieve mathematics education better than in the past.

In general, the process of learning mathematics is at schools use conventional learning models namely lectures, question and answer, assignments and learning are dominated by teachers and very few involve students. According to [17] that conventional mathematics learning results in students working procedurally and understanding mathematics without reasoning, besides the interaction between students and teachers during the 
teaching and learning process is very lacking. Assessment is one thing that is inherent in learning activities, which teachers and students must do as the party responsible for success. Authentic assessment is also called alternative assessment. Authentic assessment can be done in various ways, including portfolios and written tests.

Portfolio assessment basically assesses the work of students individually in a particular period for a particular subject. The end of a period the work is collected and assessed by the teacher and students; thus, the portfolio can show the development of student learning progress through the results of his work. While the written test is an assessment in writing where the questions and answers are given to students in written form. Therefore, the selection of learning and assessment approaches that are in accordance with the characteristics of students and fields of study can influence learning outcomes need to be proven in a study.

The general objective of this study was to determine the effect of the use of the learning approach and authentic assessment of mathematics learning outcomes after controlling for students' initial abilities.

\section{METHOD}

The method used is a $2 \times 2$ factorial design experiments by a factor approach learning and authentic assessment (Table 1). The dependent variable is the result of learning mathematics. The treatment variables are: (1) realistic mathematics education approach and the conventional approach, (2) portfolio assessment and assessment of written tests; and (3) initial mathematical abilities as covariables.

Table 1

Research Design

\begin{tabular}{|c|c|c|}
\hline \multirow{2}{*}{$\begin{array}{c}\text { Authentic } \\
\text { assessment } \\
\text { (B) }\end{array}$} & \multicolumn{2}{|c|}{ Learning Approaches (A) } \\
\hline & $\begin{array}{l}R M E\left(\mathrm{~A}_{1}\right. \\
\end{array}$ & $\begin{array}{l}\text { Conventional } \\
\left(\mathrm{A}_{2}\right)\end{array}$ \\
\hline $\begin{array}{l}\text { Portfolio } \\
\text { Assessment } \\
\left(\mathrm{B}_{1}\right)\end{array}$ & $\begin{array}{l}(\mathrm{X}, \mathrm{Y})_{11 \mathrm{k}} \\
\mathrm{k}=1,2, \ldots \\
\mathrm{n}_{11} \\
\mathrm{~A}_{1} \mathrm{~B}_{1}\end{array}$ & $\begin{array}{l}(\mathrm{X}, \mathrm{Y})_{21 \mathrm{k}} \\
\mathrm{k}=1,2, \ldots, \mathrm{n}_{12} \\
\mathrm{~A}_{2} \mathrm{~B}_{1}\end{array}$ \\
\hline $\begin{array}{l}\text { Assessment } \\
\text { of Written } \\
\text { Tests }\left(B_{2}\right)\end{array}$ & $\begin{array}{l}(\mathrm{X}, \mathrm{Y})_{12 \mathrm{k}} \\
\mathrm{k}=1,2, \ldots, \\
\mathrm{n}_{21} \\
\mathrm{~A}_{1} \mathrm{~B}_{2}\end{array}$ & $\begin{array}{l}(\mathrm{X}, \mathrm{Y})_{22 \mathrm{k}} \\
\mathrm{k}=1,2, \ldots, \mathrm{n}_{22} \\
\mathrm{~A}_{2} \mathrm{~B}_{2}\end{array}$ \\
\hline
\end{tabular}

Determination of the sample using simple random sampling technique. Mathematical learning outcomes instruments, before being used, were validated through panelists consisting of 28 questions recommended by 25 questions based on the Aiken validity index calculation and obtained the reliability coefficient (Hyot) of 0.96 . Then tested on 90 students who were not treatment classes obtained reliability coefficient (Cronbach Alpha) of 0.91. Techniques used data analysis include: Analysis of descriptive, test requirements analysis (include: normality, homogeneity, linear, significance test, regression effect, regression test, otherwise everything is tested and feasible to use inferential analysis.

\section{RESULTS}

Hypotesis testing using covariance analysis techniques (ANKOVA), in the following Table 2. Results of analysis of hypothesis 1 test, in table 2 row $A$ the value of $F$ count $=23.82$ greater than $F$ table $(0.05 ; 1.75)$ $=3.97$, When seen the corrected average value of the two groups shows that there is a group of students given the RME approach, the corrected average value of 86.29 while in the group of students given the conventional learning approach the average value was corrected by 83.50. Thus, it was concluded that the mathematics learning outcomes of groups of students given the RME approach were higher than the group of students given the conventional learning approach after controlling for students' initial abilities.

Table 2

Summary Results

\begin{tabular}{|c|c|c|c|c|c|}
\hline $\begin{array}{c}\text { Source } \\
\text { of } \\
\text { Varianc } \\
\text { e }\end{array}$ & JK & db & RJK & $\begin{array}{l}F_{\text {cou }} \\
\text { nt }\end{array}$ & $\begin{array}{l}\mathbf{F} \text { table } \\
\alpha= \\
0.05\end{array}$ \\
\hline $\begin{array}{l}\text { Covariat } \\
\text { e X }\end{array}$ & $\begin{array}{l}2362,51 \\
0\end{array}$ & 1 & $\begin{array}{l}2362 \\
510\end{array}$ & $\begin{array}{l}381 \\
058\end{array}$ & \\
\hline Inter A & 147,653 & 1 & $\begin{array}{l}147,6 \\
53\end{array}$ & $\begin{array}{l}23,8 \\
15\end{array}$ & 3.97 \\
\hline Inter B & 139,239 & 1 & $\begin{array}{l}139,2 \\
39\end{array}$ & $\begin{array}{l}22,4 \\
58\end{array}$ & \\
\hline $\begin{array}{l}\mathrm{A} * \mathrm{~B} \\
\text { interactio } \\
\mathrm{n}\end{array}$ & 345,834 & 1 & $\begin{array}{l}345,8 \\
34\end{array}$ & $\begin{array}{l}55,7 \\
81\end{array}$ & \\
\hline Mistake & 464,990 & 75 & 6,200 & & \\
\hline $\begin{array}{l}\text { Total } \\
\text { reduced }\end{array}$ & $\begin{array}{l}3700,00 \\
0\end{array}$ & 79 & & & \\
\hline
\end{tabular}

The results of a test of hypothesis analysis 2, table 2-line B shows that: $\mathrm{F}$ count $=22.46$ is greater than $\mathrm{F}$ table $(0.05 ; 1.75)=3.97$. When viewed from the corrected average value of the two groups showed that $\mathrm{p}$ there is a group of students were given a portfolio assessment, the average pitch correction at 86.36 , while group of students taught by a written test ratings average pitch correction at 83.67. Thus, it was concluded that the mathematics learning outcomes for groups of students who were given a portfolio assessment were higher than the group of students who were given a written test rating after controlling for students' initial abilities.

The results of a test of hypothesis analysis 3-line A * B in table 2 shows that $\mathrm{F}$ count $=55,781$ is greater than F table $(0.05 ; 1 ; 75)=3.97$. This means that there is an influence of the interaction between the learning approach (A) and authentic assessment (B) on the learning outcomes of mathematics after controlling for students' initial abilities. For the hypothesis test 4,5,6 and 7, the ttest is used.

The results of hypothesis 4 test analysis, show that: the value of $\mathrm{t}$ arithmetic $=9.56$ is greater than table $(0.05 ; 75)=1,66$. When seen the average value corrected both groups showed that the mathematics learning outcomes of groups of students given the RME approach had a corrected average of 89.88. Whereas in the group of students who were given the conventional approach the average value was corrected by 82.35 . Thus, it was concluded that for portfolio assessment, the mathematics learning outcomes of groups of students taught by the RME approach were higher than the group of students given the conventional approach after controlling for initial abilities. 
The results of the hypothesis test analysis 5 shows the use values $\mathrm{t}=-1.9$ is smaller than $\mathrm{t}$ table $(0.05 ; 75)=$ - 1.66. When looking at the corrected average value the two groups showed that for the assessment of the written test, the mathematics learning outcomes of the group of students given the RME approach, have an average pitch correction at 82.93, while on a group of students who were given the conventional approach has an average value of pitch correction at 84.38 . Thus, it was concluded that for the assessment of written tests, the mathematics learning outcomes of groups of students taught with the RME approach were lower from groups of students taught by conventional approaches, after controlling for students' initial abilities

The results of the hypothesis analysis are 6 , shown value of $\mathrm{t}$ count $=8.83$ greater than t table $(0.05 ; 75)=$ 1.66. When seen average values corrected k Secondly groups shows that for group of students who were given RME approach, the results of students' mathematics learning by portfolio assessment has an average corrected by 89.88 , The group of students who were given a written test assessment had a corrected average of 82,93 .Thus it was concluded that for the group of students given the RME approach, the mathematics learning outcomes of groups of students who were given a portfolio assessment were higher than the group of students who were given a written test assessment after controlling students' initial mathematical abilities.

Result hypothesis test analysis 7 shown value of $\mathrm{t}$ count $=-2.29$ smaller than $\mathrm{t}$ table $(0.05 ; 75)=-1.66$. When viewed the corrected average value of the two groups shows that for groups of students given a conventional approach, the results of mathematics learning groups of students who are given a portfolio assessment, the average value of pitch correction of 823 $5, \mathrm{~s}$ the group of students who were given a written test assessment the average value was corrected by 84.38 . Thus, it was concluded that the student group was given an approach conventionally, mathematics learning outcomes of students who were given a portfolio assessment were lower than the group of students who were given a written test assessment after controlling students' initial mathematical abilities.

\section{DISCUSSION}

First. The basic mathematics learning group of students given the RME approach was higher than the group of students who were given a conventional learning approach after controlling students' initial abilities. Theoretically approaches to RME is an approach learning in mathematics that emphasizes the process of full student involvement to be able to find material that is learned and connect it to real life situations, thus encouraging students to be able to apply it in their lives. According to [11], a realistic mathematics education or PMRI approach is one approach that will lead students to understand mathematical concepts by constructing themselves through prior knowledge related to their daily lives. By finding the concepts themselves, student learning is expected become meaningful.

This finding is in line with the research of [12], and [6] found that mathematics learning outcomes with a realistic mathematic education approach were better than students who were taught using a conventional (conventional) approach. Learning through realistic mathematics approach can enable students to reduce the dominance of the teacher, the teacher's ability to manage learning included either, so it is said to be effective.

In conventional approaches educators are people who: have a lot of information, work to move knowledge, are responsible for teaching students, all from teachers and students diligently hear and record what is dictated by the teacher so that conventional learning, does not provide opportunities for students to learn independently.

By looking at theoretical studies and paying attention to empirical data from results similar research can be stated that the RME approach is good to be implicated in mathematics learning because it can provide higher mathematics learning outcomes compared to conventional approaches.

Second, Mathematic is learning outcomes groups of students who were given a portfolio assessment were higher than the group of students who were given a written test assessment, after controlling for students' initial abilities. Theoretically, the assessment of portfolios is the process of gathering information by teachers about the development and achievement of learning carried out by students through various techniques that are able to express, prove, or show precisely that learning objectives and abilities have truly been mastered and achieved.

This finding is in line with the opinion of [9] stating that portfolio valuation is able to appreciate students as dynamic individuals, actively constructing knowledge according to their experience. According to [10] learning by using a portfolio can improve learning outcomes, get positive responses from students, teachers and parents of students, making it easier for students to understand and work on the questions given so they can produce the best. Students also find it easier to learn after all the tasks done, are included in the portfolio because the lesson notes are not lost.

$\mathrm{P}$ there is a written test assessment, test participants tend to rely solely on cognitive abilities without involving other knowledge, for mastery of mathematical understanding has not been able to provide measurements of perfect mathematics learning outcomes, is understanding mathematics requires logical thinking, critical and analytical so it takes a more comprehensive assessment process. Therefore, in mathematics learning, the assessment using a portfolio of learning outcomes will be better than using a written test assessment.

Third, there is a significant interaction effect between teaching approaches and authentic assessment of the mathematics learning outcomes after controlling for students' initial ability. Theoretically the approach to learning can be interpreted as our starting point for the learning process, which refers to the view of the occurrence of a process that is still very general in nature, which embodies, inspires, strengthens, and underlies learning methods with certain theoretical scope.

Authentic assessment is a form of assessment in which students are asked to present assignments in real situations that demonstrate the application of meaningful skills and essential knowledge. This finding is in line with 
the opinion of [7] that authentic assessment emphasizes the assessment of learning processes and outcomes so that the entire appearance of students in the learning series can be assessed objectively and not only just judge the final product. According to [15] the purpose of authentic assessment is to measure various skills in various contexts that reflect real world situations where these skills are used. Therefore, if the authentic learning and assessment approach is used in mathematics learning, the mathematics learning outcomes will increase.

Fourth, for groups of students taught with a realistic mathematics education (RME) approach, the mathematics learning outcomes of groups of students given portfolio assessments were higher than the written test scores. Theoretically, mathematics learning using the RME or PMRI approach is that learning directs students to the use of various situations or real contexts, studentcentered learning, prioritizes the meaningfulness of concepts, interactive teaching, democratic learning. While portfolio valuation is an approach or valuation model that aims to measure the ability of students to build and reflect on a work or work through collecting materials that are relevant to the goals and desires built by students so that the results of the work can be assessed and commented on by the teacher in certain period.

This finding is in line with [16] RME / PMRI is an approach that prioritizes the meaningfulness of mathematical concepts as the starting point of learning. According to [5] that the portfolio is a collection of work of students who show their business, development and skills in one or more fields. Therefore, if the mathematics learning process uses the RME approach and portfolio assessment, then the mathematics learning outcomes will be higher than the mathematics learning outcomes of students who are given a conventional approach with portfolio assessment.

Fifth, for groups of students who were given a written test assessment, mathematics learning outcomes with the RME approach was lower than the conventional learning approach, after controlling for students' initial abilities. Theoretically, conventional learning tends to be teacher-centered, student activities will be carried out individually. In conventional learning, students are trained independently in gaining knowledge with capital information from the teacher and the materials they have. Whereas the RME approach tends to be student-centered and emphasizes the context and real world of students. Learning must begin by asking the "real" problem (question) for students according to their experience and level of knowledge, so students immediately engage in the lesson meaningfully.

This finding is in line with the results of the [6] learning realistic provides clear understanding and operating the students about the relationship between a mathematics to everyday life and about the usefulness of mathematics in general for humans, mathematics a field of study that is constructed and developed by the students, how to solve problems or problems do not have to be single and do not have to be the same between one person to another, and learning mathematics must undergo a process and try to find mathematical concepts themselves with the help of other parties, with RME students trained independently in gaining knowledge. Therefore, the assessment of written tests is more suitable for use in conventional approaches.

To six, for groups of students who were given portfolio assessments, the mathematics learning outcomes of groups of students were taught using realistic mathematics education learning approaches (RME) is higher than the conventional learning approach after control ability early students. Theoretically Portfolio assessment requires students to be able to demonstrate all abilities related to mastery of cognitive, psychomotor and affective aspects. The RME or PMRI learning approach is a learning concept that helps teachers associate material taught with real situations / daily lives of students and encourages students to make connections between the knowledge they have and their application in daily life.

In conventional learning the same as classical learning or traditional learning or learning by using the lecture method, where learning is a way to convey ideas / ideas or provide information with oral or written, one-way learning process, all from the teacher, and students diligently listening and noting what was dictated by the teacher.

According [3] that results for students who are taught by mathematics realistically $\mathrm{k}$ better than students taught by conventional. The use or application of portfolio assessments has a positive impact on learning [2] Thus it can be said that if portfolio assessment is used in the RME approach, student learning outcomes will increase, rather than using a conventional approach.

Seventh, for groups of students taught by conventional approaches, mathematics learning outcomes groups of students assessed with lower portfolios than groups of students assessed by written tests after controlling for initial abilities. Theoretically, the assessment of written tests is an effective method for assessing $\mathrm{PE} \neg$ knowledge, facts, and skills that are structured through systematic procedures so that they can be used to assess the process of cognitive and important changes. $\neg$ behavior that happens to students. Assessment of written tests requires students to read, compose, or understand the concept symbolically shown.

In contrast to portfolio valuation, which basically is to assess the work of students individually in one period, is a continuous assessment based on a collection of information that shows the development of students in a given period. Thus, based on it can be said that for the assessment of written tests more suitable for use in conventional approaches.

\section{CONCLUSION}

Result research findings are the result of learning mathematics student groups taught by realistic mathematics education approach higher than the group of students taught by conventional approach, after controlling for students' initial ability. The basic mathematics learning group of students who were given a portfolio assessment higher than the group of students who were given an assessment of the real test, after controlling for students' initial abilities. There is an interaction between learning approaches and authentic assessment of mathematics learning outcomes after 
controlling for students' initial abilities. group students taught with a approach to realistic mathematics education, mathematics learning outcomes of students in higher grades with a portfolio of a group of students in grades with a written test after controlling for initial capability. The basic mathematics learning group of students who were given a written test assessment, the RME approach was lower than the conventional approach after controlling students' initial abilities. U for the group of students given portfolio assessment, mathematics learning outcomes taught with a realistic mathematics education learning approach are higher than those taught by conventional approaches after controlling students' initial abilities. Result group of students studying mathematics taught by conventional approach and the rated portfolio is lower than that taught by conventional approach and assessed by a written test after controlling for initial capability.

\section{REFERENCES}

[1] Abdurrahman, Mulyono. Pendidikan Bagi Anak Berkesulitan Belajar. Jakarta: Departemen Pendidikan \& Kebudayaan, 2003

[2] Haribowo, H. "Penilaian Portofolio Assesment." Pelangi Pendidikan, Vol. 2, No. I, 2000: 20-27.

[3] Hasanah, S. “ Pembelajaran Matematika Realistik untuk Materi Aritmatika Sosial di Kelas VII MTsN Pademawu Pamekasan.” Jurnal Pendidikan Serambi Ilmu, Vol. 10, No. 1, 2011: 32.

[4] Joubert, M., dan P, Andrews. "Using Realistic Mathematics Education with Low to Middle Attaining Pupils in Secondary School." Proceeding of the British Congrees for Mathematics Education, April 2007: 73-80.

[5] Muslich, Masnur. Authentic Assesment: Penilaian Berbasis Kelas dan Kompetensi. Bandung: PT Refika Aditama, 2010.

[6] Nanole, Martianty. "Pembelajaran Pengurangan Pecahan Melalui Pendekatan Realistik di Kelas V Sekolah Dasar.'
Jurnal Inovasi. Volume 5, Nomor 3, September 2008: 136147.

[7] Nurgiyanto, B. "Penilaian Otentik." Jurnal Cakrawala Pendidikan." (3): 251-252.

[8] Pranata, M. "Portofolio Model Desain Berbasiskan Konstruktistik." Jurnal Penelitian dan Pengembangan Pendidikan, 6, 63-81.

[9] Priyono, Utomo Dwi. "Pengembangan Model Pembelajaran Kooperatif.

[10] Matematika yang Berorientasi Pada Kepribadian Siswa di Sekolah Dasar." Jurnal Pendidikan dan Pembelajaran. Volume 18, Nomor 2, Oktober 2011: 145-152.

[11] Purwanto, Sigid Edy. "Penggunaan Model Assesmen Portofolio dalam Penilaian Proses dan Hasil Belajar Matematika Siswa SMU." Jurnal Educatio Indonesiae, Vol. 3, No. 2, Juni 2005: 123- 134.

[12] Ratu Ilma Indra Putri. "Pembelajaran Materi Bangun Datar melalui Cerita Menggunakan Pendidikan Matematika Realistik Indonesia(PMRI) di Sekolah Dasar. Jurnal Pendidikan dan Pembelajaran. Volume 18, Nomor 2, Oktober 2011: 234-239.

[13] Haji. "Pendekatan Problem Possing dalam Pembelajaran Matematika di Sekolah Dasar." Jurnal Kependidikan Triadik, Volume 14, No. 1, April 2011: 55-63.

[14] Soedjadi, R. "Pemanfaatan Realitas dan Lingkungan dalam Pembelajaran Matematika." Papers presented Seminar Nasional Realistic Mathematics Education (RME) FMIPA UNESA, 24 February.

[15] Suruddin. "Pengaruh Penilaian berbasis Kelas dan Metode Pembelajaran Hasil Belajar Matematika setelah Mengontrol Pengetahuan Awal Matematika Siswa." Jurnal Evaluasi Pendidikan, Vol. 1, No. 1, Maret 2010: 36- 45.

[16] Widhiarso, W. Penerapan Assesmen Potofolio dalam Pengukuran Kompetensi Mahasisa dalam Melakukan Assesmen Psikologi. Yogyakarta: Fakultas Psikologi Universitas Gajah Mada, 2004.

[17] Wijaya, A. Pendidikan Matematika Realistik. Yogyakarta: Graha Ilmu, 2011.

[18] Yuwono, Ipung. "RME (Realistic Mathematic Education) dan Hasil Study Awal Implementasinya di SLTP.” Papers presented Seminar Nasional Realistic Mathematics Education (RME) FMIPA UNESA, 24 February. 